\title{
Analisis Premi dari Asuransi Pengangguran
}

\author{
I Nyoman Widana \\ Program Studi Matematika, Fakultas MIPA - Universitas Udayana \\ widana@ unud.ac.id \\ Ketut Jayanegara \\ Program Studi Matematika, Fakultas MIPA - Universitas Udayana \\ ktjayanegara@unud.ac.id
}

\begin{abstract}
Unemployment insurance is designed to overcome some of the financial problems faced by workers who have been involuntarily terminated from their jobs. The benefit insurance is financed based on the contributory from an employer, employee or government in recent times, some developing countries have been establishing unemployment insurance. This research aims to analyze the unemployment insurance products in Indonesia. Especially to analyze the financial viability of the product. The method used is the equivalence premium principle. Based on data sourced from BPJS Ketenagakerjaan and a claim rate of 10\%, it is found that a premium rate of $5 \%$ of insured wages would support a benefit level of $50 \%$ of the wages for 43 weeks. This premium rate would also support $70 \%$ of the wages for 32 weeks. Meanwhile, the premium rate of $1 \%$ of the participant wages would guarantee a benefit level of 50\% for 6 weeks.
\end{abstract}

Keywords: Premium Rate, Unemployment Insurance.

\section{Pendahuluan}

Dari tahun ke tahun jumlah penduduk Indonesia selalu mengalami peningkatan. Indonesia dengan jumlah penduduk sekitar 260 juta jiwa memiliki angkatan kerja sangat besar. Tetapi Jumlah lapangan kerja yang tersedia tidak mampu menyerap semua angkatan kerja ini. Menurut Badan Pusat Statistik (BPS) pada Februari 2018, angka pengangguran mencapai 6,87 juta orang atau sekitar 5,13\% dari total tenaga kerja. Selain itu angka pemutusan hubungan kerja (PHK) juga relatif masih tinggi. Hal ini membuat pemerintah mengeluarkan wacana program asuransi pengangguran (unemployment insurance) yang diharapkan bisa membantu secara finansial bagi pekerja yang mengalami PHK.

Asuransi pengangguran, merupakan suatu jaminan sosial yang diberikan oleh perusahan asuransi bagi peserta asuransi yang kehilangan pekerjaannya. Asuransi ini pertama kali didirikan oleh Foundry Men`s Union di Britania pada tahun 1832 . Adapun tujuannya adalah untuk mengatasi sebagian dari masalah finansial yang diakibatkan oleh pemutusan hubungan kerja. Untuk bisa memperoleh benefit dari program ini, peserta diwajibkan membayar sejumlah uang (premi) yang besarnya 
berkaitan dengan besarnya upah atau penghasilan yang diterima.

Jackie (2000) menyatakan bahwa menurut Konvensi ILO pengangguran yang memenuhi syarat untuk mendapatkan jaminan dari program asuransi pengangguran ruang lingkupnya meliputi:(1) pengangguran itu harus tidak dikehendaki(involuntary unemployment), (2) pengangguran harus bersifat sementara(temporary unemployment), (3) penganggur, yang akan mendapat benefit ini, harus telah mempunyai pekerjaan sebagai sumber penghidupannya (bukan yang untuk baru mau bekerja), (4) penganggur tersebut harus tetap mampu bekerja, (5) penganggur harus tetap bersedia untuk bekerja kembali, dan (6) penganggur harus bersedia menerima pekerjaan yang cocok (suitable employment).

Program Asuransi pengangguran tentunya sangat bermanfaat bagi karyawan yang mengalami PHK atau menganggur. Selanjutnya, program ini dapat juga ditawarkan sebagai alternatif untuk mengatasi masalah kemiskinan dan kesenjangan di negara kita. Sejauh ini Badan Penyelenggara Jaminan Sosial (BPJS) yang bertugas memberikan perlindungan pekerja hanya menawarkan program jaminan kecelakaan kerja, jaminan kematian, jaminan hari tua, dan dana jaminan pensiun. Selain itu, beberapa negara maju sudah menerapkan program ini. Sehingga untuk itu program Asuransi Pengangguran perlu dipertimbangkan sebagai salah satu alternatif untuk memecahkan masalah-masalah sosial yang diakibat oleh adanya PHK. Berdasarkan hal ini penelitian ini akan menganalisis premi dari asuransi pengangguran.

\section{Metode Penelitian}

Penelitian ini memanfaatkan data sekunder yang diperoleh dari BPJS Ketenagakerjaan yang ada di Indonesia. Adapun datanya antara lain meliputi, rata-rata besar upah total berdasarkan skala usaha dari peserta BPJS Ketenagakerjaan. Adapun tahapan analis yang dilakukan dalam penelitian ini adalah sebagai berikut:

1. Mengumpulkan data dari BPJS ketenagakerjaan yang meliputi antara lain besar gaji rata-rata per bulan dari peserta BPJS.

2. Menghitung besar gaji rata-rata per minggu dari peserta BPJS.

3. Menghitung besar manfaat asuransi pengangguran (unemployment benefit) per minggu per orang untuk tingkat penggantian (replacement rate) sebesar 50\%, 60\% dan $70 \%$ dari besar gajinya per minggu.

4. Menghitung rata-rata biaya per penerima manfaat (average cost per beneficiary) dari pembayaran benefit untuk pertanggungan selama 5 minggu.

5. Mengestimasi jumlah peserta program asuransi pengangguran yang akan mengajukan klaim benefit dalam waktu satu tahun.

6. Menghitung besar ekspektasi benefit yang diterima oleh peserta untuk pertanggungan selama 5 minggu untuk berbagai tingkat penggantian. 
7. Menghitung besar pendapatan dari iuran premi untuk tingkat retribusi sebesar $1 \%, 2 \%, 3 \%, 4 \%$ dan $5 \%$ dari gaji peserta asuransi.

8. Menganalisis hubungan besar premi dengan jangka waktu pertanggungan dengan menggunakan prinsip ekuivalensi. yang dapat dinyatakan dalam bentuk

dengan

$$
P V(I)=P V(B)+P V(E)
$$

$P V(I), P V(B)$, dan $P V(E)$ berturut-turut menyatakan nilai tunai dari pendapatan premi, nilai tunai dari pembayaran benefit dan nilai tunai biaya.

\section{Hasil dan Pembahasan}

\subsection{Gaji dan Benefit}

Pada bagian ini akan ditampilkan asumsi pertumbuhan upah dari tahun 2017 2021. Data ini diperoleh dari laporan tahunan BPJS Ketenagakerjaan yang merupakan publik entitas yang berpotensi untuk mengelola dana dari Asuransi pengangguran.

Tabel 1. Rata-rata Upah

\begin{tabular}{|l|rrrr|}
\hline \multirow{2}{*}{ Tahun } & \multicolumn{4}{|c|}{ Rata-rata Upah Total Berdasarkan Skala Usaha } \\
\cline { 2 - 5 } & Besar & Menengah & Kecil & Mikro \\
\hline $\mathbf{2 0 1 7}$ & 5.242 .329 & 3.735 .543 & 2.652 .434 & 2.072 .557 \\
$\mathbf{2 0 1 8}$ & 6.219 .987 & 4.248 .866 & 2.860 .713 & 2.255 .644 \\
$\mathbf{2 0 1 9}$ & 7.379 .972 & 4.832 .728 & 3.085 .346 & 2.454 .905 \\
\hline $\mathbf{2 0 2 0}$ & 8.666 .527 & 5.453 .512 & 3.311 .817 & 2.657 .625 \\
\hline $\mathbf{2 0 2 1}$ & 10.072 .312 & 6.105327 & 3.538 .008 & 2.861 .826 \\
\hline
\end{tabular}

Sumber: Deputi Direktur Bidang Perluasan Kepesertaan

Berdasarkan data dari Tabel 1, khususnya data rata-rata upah pada tahun 2020, diperoleh rata-rata gaji per minggu untuk sksla usaha besar, menengah, kecil, dan makro berturut-turut adalah sekitar: $R p 2.000 .000, R p 1.259 .000, R p 764.000$, dan Rp613.000.

Atas dasar rata-rata gaji untuk skala usaha kecil, besar manfaat (benefit) per minggu per orang untuk berbagai tingkat penggantian (replacement rate) adalah sebagai berikut

Tabel 2. Tingkat Penggantian dan Benefit

\begin{tabular}{|c|c|}
\hline Tingkat Penggantian & Besar Manfaat per Minggu (rupiah) \\
\hline $50 \%$ & 382000 \\
\hline $60 \%$ & 458400 \\
\hline $70 \%$ & 534800 \\
\hline
\end{tabular}


Selanjutnya, akan ditampilkan ekspektasi dari besar manfaat untuk tingkat klaim sebesar 10\%, lama pembayarannya selama 5 minggu dan bebagai tingkat penggantian.

Tabel 3. Benefit Selama 5 Minggu

\begin{tabular}{|c|c|}
\hline Tingkat Penggantian & Ekspektasi Benefit per Orang \\
\hline $50 \%$ & 191066.3654 \\
\hline $60 \%$ & 229279.6385 \\
\hline $70 \%$ & 267492.9115 \\
\hline
\end{tabular}

\subsection{Tingkat Retribusi dan Analisis Hasil}

Pada penelitian ini diasumsikan biaya administrasinya sebesar $0,4 \%$ dari gaji peserta. Maka besar pendapatan dari premi dengan tingkat retribusi sebesar $1 \%, 2 \%, 3 \%, 4 \%$ dan $5 \%$ dari gaji peserta berturut-turut adalah sebagai berikut: 238450, 635870, 1033290, 1430700 dan 1828120 rupiah. Berdasarkan hal ini dan Tabel 2 serta mengingat prinsip ekuivalensi maka diperoleh hasil sebagai berikut. Untuk pembayaran premi sebesar 5\% dari gaji, maka dana ini akan cukup untuk membayarkan benefit sebesar:

- $50 \%$ dari gaji selama 43 minggu. Atau

- $60 \%$ dari gaji selama 37 minggu. Atau

- $70 \%$ dari gaji selama 32 minggu

Hasil perhitungan selengkapnya disajikan pada Gambar 1.

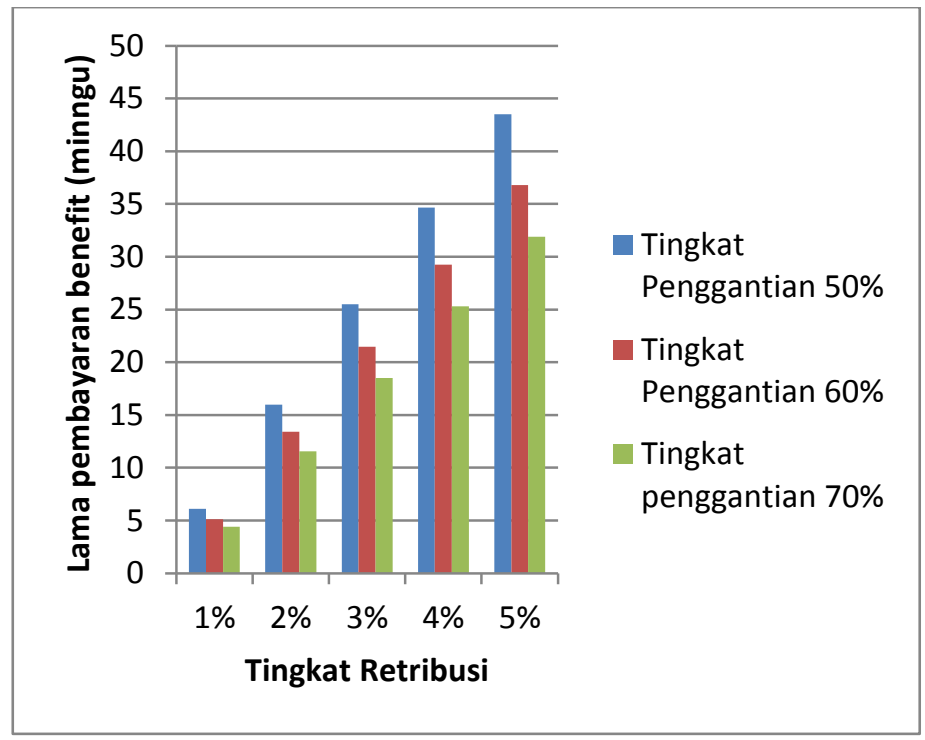

Gambar 1. Tingkat Retribusi dan Lama pembayaran Benefit

Perlu juga dicatat bahwa hasil yang sama diperoleh untuk sksla usaha besar, menengah, dan makro. 


\section{Simpulan dan Saran}

Hasil Simpulan yang dapat diambil sejauh ini, untuk tingkat klaim sebesar 10\%, adalah sebagai berikut:

- Iuran premi sebesar 5\% dari gaji akan cukup untuk mendanai pembayaran benefit sebesar 50\% dari gajinya per minggu selama 43 Minggu. Atau alternatif lain, peserta akan mendapatkan 70\% dari gajinya selama 32 Minggu.

- Iuran premi sebesar 3\% dari gajinya. akan cukup untuk mendanai benefit sebesar 50\% dari gajinya selama 25 Minggu. Atau alternatif lain, peserta akan mendapatkan 70\% dari gajinya selama 18 Minggu.

- Iuran premi sebesar 1\% dari gaji akan cukup untuk mendanai benefit sebesar $50 \%$ dari gajinya per minggu selama 6 Minggu. Atau alternatif lain, peserta akan mendapatkan 70\% dari gajinya selama 4 Minggu.

Pada penelitian ini perhitungan premi menggunakan asumsi zero mortality. Untuk penelitian selanjutnya, penentuan besar preminya dapat dilakukan dengan menggunakan asumsi non-zero mortality.

\section{Daftar Pustaka}

Bowers NL, Gerber H.U., Hickman, J.C., Jones, D.A., dan Nesbitt, C.J. 1997. Actuarial Mathematics. Schaumburg (DE): The Society of Actuaries. Terjemahan dari; Seimei Hoken Sugaku, Jokan (" 92 Revision).

BPJS Ketenagakerjaan. 2017. Laporan Tahunan 2017. (On-line). www.bpjsketenagakerjaan.go.id. Diakses 8 Mei 2019.

Dickson, D.C.M., Hardy, M.R. \& Waters, H.R., 2009. Actuarial Mathematics for Life Contingent Risk. New York: Cambridge University Press.

Jackie WU., 2000. Unemployment Benefits Systems: the International Labour Organization's Recommendations. Hongkong

Kithinji M.M. 2016. Pricing Unemployment Insurance Assuming Burr XII Mixture Distributions and C.A.P.M With Application To USA Data. Dissertation University of Nairobi.

Kithinji M.M., Simwa R.O., and Otieno J.A.M. 2016. Pricing Unemployment Insurance Assuming Burr Xii Mixture Distribution To Model Unemployment. International Journal of Emerging Technology \& Research.

Narine T. 2016. Modeling the Unemployment Risk in Insurance Products Actuarial Mathematics. Schaumburg (DE): The Casuality Actuarial Society, Canadian Institut of Actuaries, Society of Actuaries. 
O'Leary C.J. Narine T. 1997. Unemployment Insurance in the United States: Analysis of Policy Issues. W.E. Upjohn Institut for Employment Research. Michigan.

Plamondon P., Binet G., Cichon M., Gillvray W.R., Bordad M., dan Montas H.P. 2002. Actuarial Practise in Social Sequrity. International Labour Organization.

Simwa R.O., 2018. On Pricing of Unemployment Insurance Assuming Non-Zero Mortality for Employees with Application to the USA. Economy. European Journal of Statistics and Probability. 